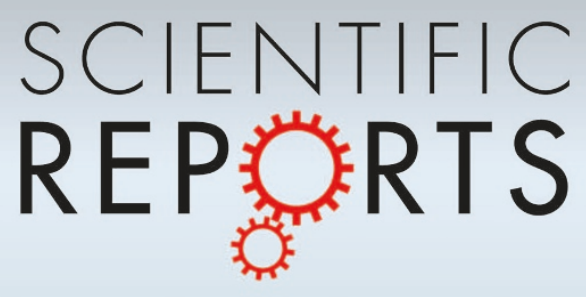

OPEN

\title{
Electrochemical properties of cobalt hydroxychloride microspheres as a new anode material for Li-ion batteries
}

\author{
Gi Dae Park, You Na Ko \& Yun Chan Kang
}

SUBJECT AREAS:

CERAMICS

BATTERIES

SYNTHESIS AND PROCESSING

Received

11 February 2014

Accepted

23 April 2014

Published

29 August 2014

Correspondence and requests for materials should be addressed to

Y.C.K. lyckang@ konkuk.ac.kr)
Department of Chemical Engineering, Konkuk University, 1 Hwayang-dong, Gwangjin-gu, Seoul 143-701, Korea.

The use of cobalt hydroxychloride $\left[\mathrm{Co}_{2}(\mathrm{OH})_{3} \mathrm{Cl}\right]$ as an anode material for lithium ion batteries (LIBs) is investigated using spherical shape and ultrafine nanocrystals directly formed by spray pyrolysis from spray solution of cobalt chloride salt. Dot-mapping images of the resulting powders reveal a uniform distribution of $\mathrm{Co}, \mathrm{O}$, and $\mathrm{Cl}$ throughout the powder. The $\mathrm{Co}_{2}(\mathrm{OH})_{3} \mathrm{Cl}$ powder prepared directly by spray pyrolysis exhibits a high thermal stability at temperatures below $220^{\circ} \mathrm{C}$, as well as having superior electrochemical properties compared with those of the $\mathrm{CoCl}_{2}\left(\mathrm{H}_{2} \mathrm{O}\right)_{2}$ and $\mathrm{CoO}$ powders prepared by the same process. The initial discharge capacities of the $\mathrm{Co}_{2}(\mathrm{OH})_{3} \mathrm{Cl}$ and $\mathrm{CoO}$ powders at a constant current density of $1000 \mathrm{~mA}$ $\mathrm{g}^{-1}$ are found to be 1570 and $1142 \mathrm{~mA} \mathrm{~h} \mathrm{~g}^{-1}$, respectively, and their initial Coulombic efficiencies are 72 and $70 \%$. The discharge capacities of the $\mathrm{Co}_{2}(\mathrm{OH})_{3} \mathrm{Cl}$ and $\mathrm{CoO}$ powders after 100 cycles are 955 and $632 \mathrm{~mA} \mathrm{~h}$ $\mathrm{g}^{-1}$, respectively. The $\mathrm{Co}_{2}(\mathrm{OH})_{3} \mathrm{Cl}$ powders have a high discharge capacity of $609 \mathrm{~mA} \mathrm{~h} \mathrm{~g}^{-1}$ even after 1000 cycles at a high current density of $5000 \mathrm{~mA} \mathrm{~g}^{-1}$.

T he high energy density of lithium ion batteries (LIBs) makes them suitable for various applications, ranging in size from portable electronic devices to zero-emission vehicles, but existing LIB technology is rapidly reaching its limits in terms of energy density (per volume) and specific energy (per weight) ${ }^{1-3}$. At present, graphitic materials are widely used as the anode material in lithium-ion batteries, mostly due to their low price and high reversibility. However, graphitic anodes inherently exhibit a relatively low capacity value (theoretical value equal to $372 \mathrm{~mA} \mathrm{~h} \mathrm{~g}^{-1}$ ), and are thus inadequate for high power applications ${ }^{4-7}$. In order to ensure the successful use of Li-ion batteries in a wider variety of applications, for example electric cars, it is imperative to overcome at least some of the challenges related to obtaining a higher energy density, longer cycle life, improved high rate capability and greater safety ${ }^{8-13}$. A great deal of attention has therefore been focused on the anode materials used, as there is significant potential in this area for greatly improving battery performance ${ }^{2,14-19}$; the use of a more suitable anode material being by far the most effective means of achieving a high performance. To this end, metal oxides, sulfides, nitrides, fluorides, and oxysulfides have all been extensively explored as potential anode materials for lithium ion batteries ${ }^{20-29}$; their attraction being their ability to store excess lithium ions by a conversion reaction that results in a significantly larger reversible capacity than graphite.

Recently, copper hydroxychloride $\left[\mathrm{Cu}_{2} \mathrm{Cl}(\mathrm{OH})_{3}\right]$ was studied as a promising anode material for $\mathrm{LIBs}^{30}$, this material being able to reversibly store and release $\mathrm{Li}$ ions via a conversion reaction that is widely observed in $\mathrm{CuO}$ and $\mathrm{CuS}$ electrodes. The discharge capacities of chemically synthesized $\mathrm{Cu}_{2} \mathrm{Cl}(\mathrm{OH})_{3}$ powders at a low current density of $100 \mathrm{~mA} \mathrm{~g}^{-1}$ were found to be 1100 and $430 \mathrm{~mA} \mathrm{~h} \mathrm{~g}^{-1}$ for the $1^{\text {st }}$ and $20^{\text {th }}$ cycles, respectively. Moreover, although copper based materials containing $\mathrm{CuO}$ and $\mathrm{CuS}$ have poor electrochemical properties compared with the other transition metal-based materials such as $\mathrm{Co}, \mathrm{Mn}$, and Fe; metal hydroxychlorides excluding copper have not been studied as potential electrode materials for LIBs to the best of the authors' knowledge $e^{20-23,31-33}$.

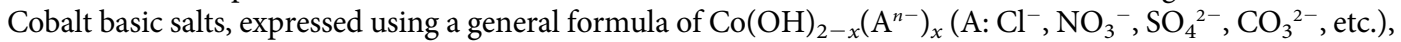
have been extensively studied over the last two decades because of the important electric, magnetic, and catalytic properties of the metal oxides formed upon their thermal decomposition ${ }^{34-37}$. However, the preparation process to obtain cobalt basic salts with controlled morphologies, and their resulting electrochemical properties, have not been reported. In this study, cobalt hydroxychloride $\left[\mathrm{Co}_{2}(\mathrm{OH})_{3} \mathrm{Cl}\right]$ is therefore studied for the first time as a potential anode material for LIBs. The spherical shape of $\mathrm{Co}_{2}(\mathrm{OH})_{3} \mathrm{Cl}$ powders produced by a simple one-pot spray pyrolysis process is found to result in superior electrochemical properties. Furthermore, the discharge capacity of bare $\mathrm{Co}_{2}(\mathrm{OH})_{3} \mathrm{Cl}$ powders, i.e., without carbonaceous materials generally improve the electrical 
conductivity as well as acting as buffer layer for large volume changes during cycling, was high as $609 \mathrm{~mA} \mathrm{~h} \mathrm{~g}^{-1}$ after 1000 cycles at a high current density of $5000 \mathrm{~mA} \mathrm{~g}^{-1}$.

\section{Results}

The crystal structures of the powders were found to be strongly affected by their respective preparation temperatures, as shown in Figure 1. Those powders prepared at temperatures of 500 and $900^{\circ} \mathrm{C}$ had primary crystal structures of $\mathrm{CoCl}_{2}\left(\mathrm{H}_{2} \mathrm{O}\right)_{2}$ and $\mathrm{CoO}$, respectively; however, the XRD pattern of the powders prepared directly by spray pyrolysis at $700^{\circ} \mathrm{C}$ indicated main peaks of $\mathrm{Co}_{2}(\mathrm{OH})_{3} \mathrm{Cl}$ crystals, and minor peaks of $\mathrm{CoCl}_{2}\left(\mathrm{H}_{2} \mathrm{O}\right)_{2}$ and $\mathrm{CoO}$ crystals. Decomposition of $\mathrm{Co}_{2}(\mathrm{OH})_{3} \mathrm{Cl}$ into $\mathrm{CoO}$ was found to occur at a high preparation temperature of $900^{\circ} \mathrm{C}$ under a nitrogen atmosphere; and consequently, the optimum direct preparation temperature for $\mathrm{Co}_{2}(\mathrm{OH})_{3} \mathrm{Cl}$ powders by spray pyrolysis is located somewhere between 500 and $900^{\circ} \mathrm{C}$.

The $\mathrm{Co}_{2}(\mathrm{OH})_{3} \mathrm{Cl}$ powders prepared directly by spray pyrolysis at $700^{\circ} \mathrm{C}$ were found to have a spherical shape and porous structure, as shown by the SEM and TEM images in Figures $2 \mathrm{a}-2 \mathrm{~d}$. Moreover, the high resolution TEM image in Figure 2e shows the presence of ultrafine nanocrystals of less than $10 \mathrm{~nm}$ in size, with clear lattice fringes separated by 0.59 and $0.42 \mathrm{~nm}$. The dot-mapping images of the powders, as shown in Figure $2 \mathrm{f}$, reveal a uniform distribution of $\mathrm{Co}, \mathrm{O}$, and $\mathrm{Cl}$ throughout the powder. The $\mathrm{Co}_{2}(\mathrm{OH})_{3} \mathrm{Cl}$ powder exhibiting both a spherical shape and ultrafine nanocrystals was directly formed from a single droplet of cobalt chloride salt by means of drying and decomposition.

Figures $3 \mathrm{a}$ and $3 \mathrm{~b}$ show the EDX spectrum and thermogravimetric (TG) curve, respectively, for $\mathrm{Co}_{2}(\mathrm{OH})_{3} \mathrm{Cl}$ powders prepared directly by spray pyrolysis at $700^{\circ} \mathrm{C}$. The respective concentrations of $\mathrm{Co}, \mathrm{O}$, and $\mathrm{Cl}$ were determined from the EDX spectrum as 45.4, 29.1, and 25.5 atomic\%; and the mole ratio of the $\mathrm{Co}_{2}(\mathrm{OH})_{3} \mathrm{Cl}$ and $\mathrm{CoCl}_{2}\left(\mathrm{H}_{2} \mathrm{O}\right)_{2}$ phases was estimated at $0.92: 0.08$ when the $\mathrm{CoO}$ content of the powders was ignored. The TG curve for the powders measured under air atmosphere exhibited three distinct weight losses below $1200^{\circ} \mathrm{C}$; the reaction occurring with each decrease in weight being described in Figure $3 \mathrm{~b}$ and summarized as follows: The first weight loss occurs below $380^{\circ} \mathrm{C}$, and is due to the oxidation of $\mathrm{Co}_{2}(\mathrm{OH})_{3} \mathrm{Cl}$ to form $\mathrm{CoCl}_{2}, \mathrm{CoO}_{3}$, and $\mathrm{H}_{2} \mathrm{O}^{34}$; the second weight loss occurs between 400 and $600^{\circ} \mathrm{C}$, due to the decomposition of $\mathrm{CoCl}_{2}$ into $\mathrm{Co}_{3} \mathrm{O}_{4}{ }^{38}$; and the final weight loss occurs above $1100^{\circ} \mathrm{C}$, due to the reduction of $\mathrm{Co}_{3} \mathrm{O}_{4}$ into $\mathrm{CoO}^{39}$. Despite this, the cobalt hydroxychloride prepared directly by spray pyrolysis had high thermal stability at temperatures below $220^{\circ} \mathrm{C}$. Figure S1a shows the $\mathrm{N}_{2}$ adsorption and desorption isotherms of the powders prepared by

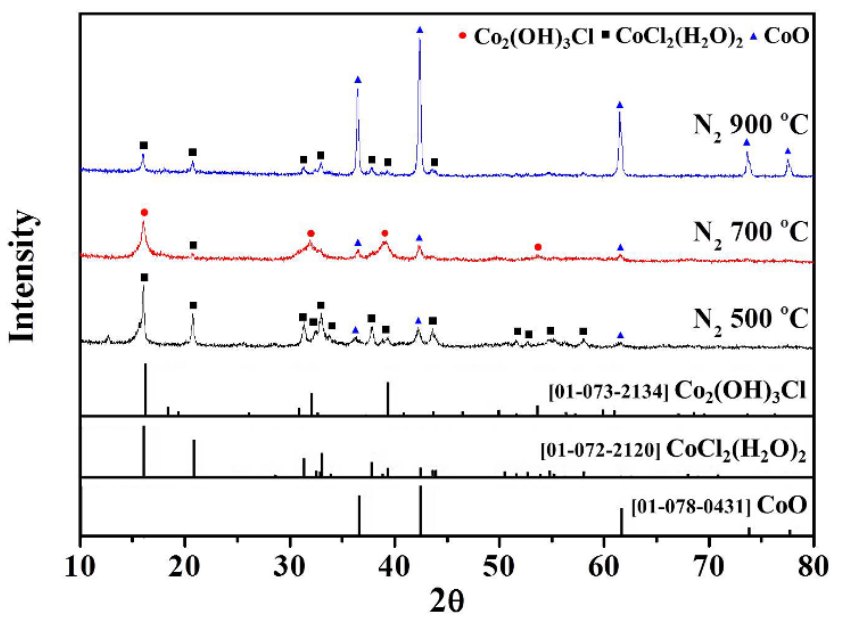

Figure $1 \mid$ XRD patterns of the powders prepared by spray pyrolysis at various temperatures. spray pyrolysis of a solution containing cobalt chloride at various temperatures, in which the hysteresis loops resemble the type- $\mathrm{H} 3$ IUPAC (International Union of Pure and Applied Chemistry) isotherm classification. The pore size distributions, as shown in Figure $\mathrm{S} 1 \mathrm{~b}$, indicate that the powders have a mesoporous structure irrespective of their preparation temperature. The BET surface areas of the powders prepared at 500,700 , and $900^{\circ} \mathrm{C}$ were subsequently determined as 13,6 , and $4 \mathrm{~m}^{2} \mathrm{~g}^{-1}$, respectively.

The electrochemical properties of those powders with primary crystal structures of $\mathrm{CoCl}_{2}\left(\mathrm{H}_{2} \mathrm{O}\right)_{2}, \mathrm{Co}_{2}(\mathrm{OH})_{3} \mathrm{Cl}$, and $\mathrm{CoO}$ were investigated in the voltage range of $0.001-3 \mathrm{~V}$ vs. $\mathrm{Li} / \mathrm{Li}^{+}$. Figure $4 \mathrm{a}$ shows the resulting initial discharge and charge voltage profiles at a constant current density of $1000 \mathrm{~mA} \mathrm{~g}^{-1}$, from which it can be seen that the $\mathrm{CoO}$ powders prepared at $900^{\circ} \mathrm{C}$ produce two plateaus in the first discharging process. The first of these plateaus, appearing near $0.9 \mathrm{~V}$, is associated with lithium storage in $\mathrm{CoO}^{40-42}$; whereas the second plateau located near $0.6 \mathrm{~V}$ can be ascribed to the conversion reaction between $\mathrm{CoO}$ and $\mathrm{Li}^{40-42}$. The slope, which is observed in the voltage range between 0.5 and $0.01 \mathrm{~V}$, can be attributed to the interaction between Co particles and the electrolyte to form a solid electrolyte interface layer ${ }^{40-42}$. Conversely, the $\mathrm{Co}_{2}(\mathrm{OH})_{3} \mathrm{Cl}$ powders with small amounts of $\mathrm{CoCl}_{2}\left(\mathrm{H}_{2} \mathrm{O}\right)_{2}$ and $\mathrm{CoO}$ impurities produced several plateaus in the first discharging and charging profiles. Compositionally, $\mathrm{Co}_{2}(\mathrm{OH})_{3} \mathrm{Cl}$ is a solid solution of $\mathrm{Co}(\mathrm{OH})_{2}$ and $\mathrm{CoCl}_{2}^{43}$; therefore, $\mathrm{Co}_{2}(\mathrm{OH})_{3} \mathrm{Cl}$ reacts with $\mathrm{Li}$ according to the following reactions: $\mathrm{CoCl}_{2}+2 \mathrm{Li}^{+}+2 e^{-} \leftrightarrows \mathrm{Co}+2 \mathrm{LiCl}$ and $\mathrm{Co}(\mathrm{OH})_{2}$ $+2 \mathrm{Li}^{+}+2 e^{-} \leftrightarrows \mathrm{Co}+2 \mathrm{LiOH}^{44,45}$. The subsequent conversion reaction of $\mathrm{LiOH}$ to $\mathrm{Li}_{2} \mathrm{O}$ and $\mathrm{LiH}$ could be responsible for generating the additional discharge capacity ${ }^{46}$. As a result, the $\mathrm{Co}_{2}(\mathrm{OH})_{3} \mathrm{Cl}$ powders have a higher initial discharge capacity than $\mathrm{CoO}$ powders. Furthermore, the lithium insertion and extraction processes of $\mathrm{Co}_{2}(\mathrm{OH})_{3} \mathrm{Cl}$ powders occur by a conversion reaction similar to that of transition metal oxides, as suggested by Tarascon et al. and $\mathrm{Hu}$ et al. ${ }^{9,46}$ In this, crystalline Co nanoclusters and amorphous-like $\mathrm{LiCl}$ and $\mathrm{LiOH}$ could be formed by reactions of $\mathrm{Co}(\mathrm{OH})_{2}$ and $\mathrm{CoCl}_{2}$ with $\mathrm{Li}$ in the first discharging process. The initial discharge capacities of the $\mathrm{Co}_{2}(\mathrm{OH})_{3} \mathrm{Cl}$ and $\mathrm{CoO}$ powders were found to be 1570 and $1142 \mathrm{~mA} \mathrm{~h} \mathrm{~g}^{-1}$, respectively; while their initial Coulombic efficiencies were 72 and $70 \%$. Conversely, those $\mathrm{CoCl}_{2}\left(\mathrm{H}_{2} \mathrm{O}\right)_{2}$ powders prepared at a low temperature of $500^{\circ} \mathrm{C}$ had initial discharge and charge capacities of 1146 and $588 \mathrm{~mA} \mathrm{~h} \mathrm{~g}{ }^{-1}$; while their corresponding Coulombic efficiency was $51 \%$. Figure 4 b shows the cyclic voltammograms (CVs) of $\mathrm{Co}_{2}(\mathrm{OH})_{3} \mathrm{Cl}$ powders for the first 5 cycles, in which the change in the discharging processes clearly alters the cathodic peak positions during cycling. The main cathodic peaks for the first and second discharging processes were observed at 0.9 and $1.7 \mathrm{~V}$, but were subsequently moved to the lower-voltage regions during subsequent cycles. The remarkable differences in potential between the first and subsequent discharge curves were also observed, as shown in Figure S2. These results indicate that the original structure of the $\mathrm{Co}_{2}(\mathrm{OH})_{3} \mathrm{Cl}$ cannot be reversibly recovered after the first discharge process.

Figure $4 \mathrm{c}$ shows the cycling performances of the powders prepared at various temperatures at a constant current density of $1000 \mathrm{~mA}$ $\mathrm{g}^{-1}$. The discharge capacities of those powders prepared at $700^{\circ} \mathrm{C}$, and having a primary crystal structure of $\mathrm{Co}_{2}(\mathrm{OH})_{3} \mathrm{Cl}$, decreased from 1570 to $872 \mathrm{~mA} \mathrm{~h} \mathrm{~g}^{-1}$ for the first 8 cycles; but then slightly increased to $955 \mathrm{~mA} \mathrm{~h} \mathrm{~g}^{-1}$ during the subsequent 93 cycles. This initial decrease in the discharge capacities (2-7 cycles) was related to the transformation of the crystalline structure to a stable amorphous-like structure during cycling ${ }^{47,48}$. On the other hand, the discharge capacities of those powders prepared at $900^{\circ} \mathrm{C}$, with a primary crystal structure of $\mathrm{CoO}$, decreased steadily from 1142 to $632 \mathrm{~mA} \mathrm{~h} \mathrm{~g}^{-1}$ over 100 cycles. Additionally, the $\mathrm{Co}_{2}(\mathrm{OH})_{3} \mathrm{Cl}$ powders with ultrafine crystallite sizes are shown to have better cycling performance than $\mathrm{CoO}$ powders with a high crystallinity. The 


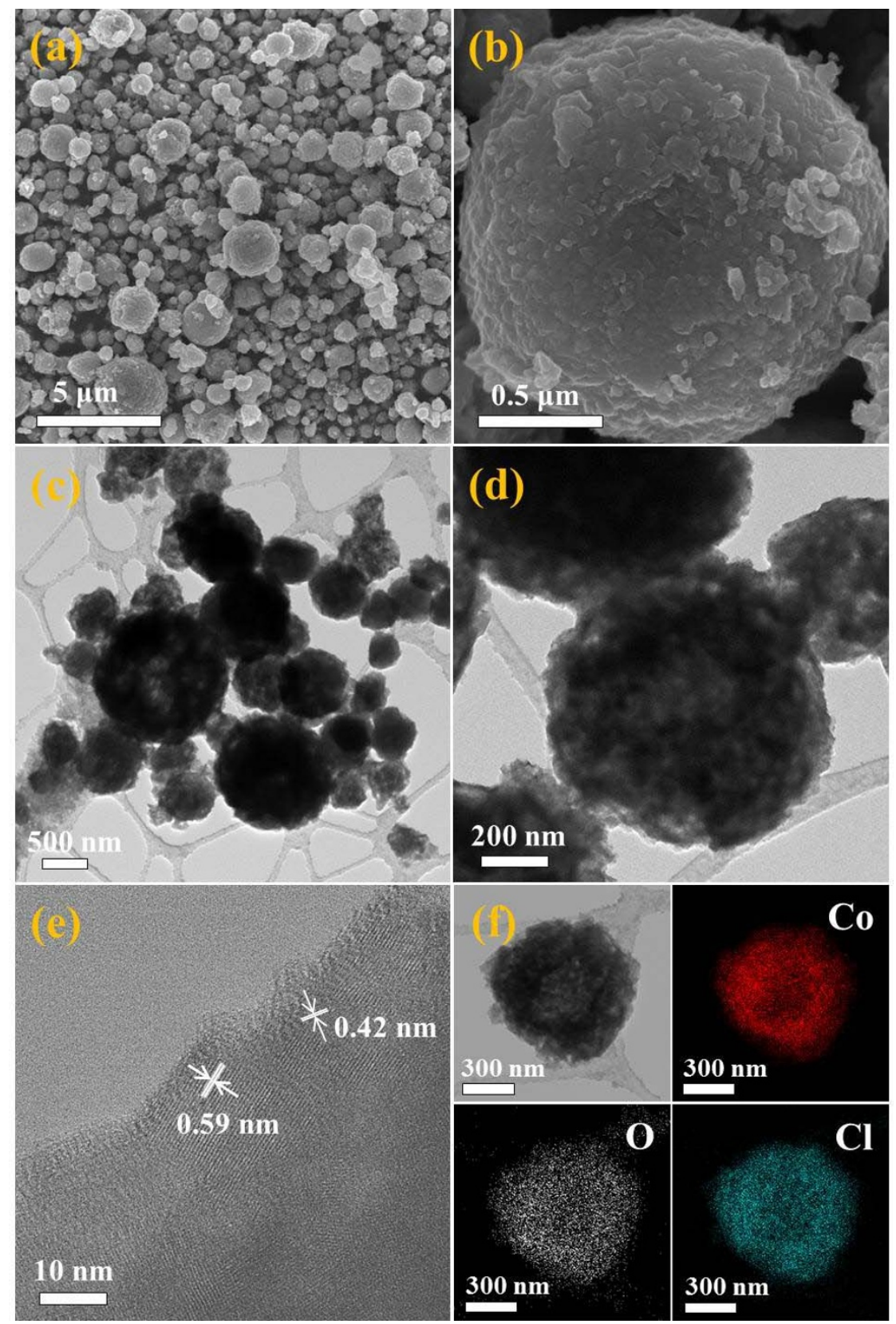

Figure $2 \mid$ Morphologies and dot-mapping images of the $\mathrm{Co}_{2}(\mathrm{OH})_{3} \mathrm{Cl}$ powders prepared at $700^{\circ} \mathrm{C}$ : (a) and (b) SEM images, (c) and (d) TEM images, (e) high resolution TEM image, and (f) dot-mapping images.

$\mathrm{CoCl}_{2}\left(\mathrm{H}_{2} \mathrm{O}\right)_{2}$ powders prepared at a low temperature of $500^{\circ} \mathrm{C}$ had low discharge capacities of 1146 and $478 \mathrm{~mA} \mathrm{~h} \mathrm{~g}^{-1}$ for the $1^{\text {st }}$ and $100^{\text {th }}$ cycles, respectively. The Coulombic efficiencies of the $\mathrm{Co}_{2}(\mathrm{OH})_{3} \mathrm{Cl}$ powders reached above $99 \%$ from the $7^{\text {th }}$ cycle at a current density of $1000 \mathrm{~mA} \mathrm{~g}^{-1}$ as shown in Figure 4c. The rate performance of the $\mathrm{Co}_{2}(\mathrm{OH})_{3} \mathrm{Cl}$ powders prepared at $700^{\circ} \mathrm{C}$ was demonstrated by the stepwise increase in Figure $4 \mathrm{~d}$ from 500 to $5000 \mathrm{~mA} \mathrm{~g}^{-1}$ and the return to $500 \mathrm{~mA} \mathrm{~g}^{-1}$ in the voltage range of 0.001-3 V. For each step, 10 cycles were measured to evaluate the rate performance. The $\mathrm{Co}_{2}(\mathrm{OH})_{3} \mathrm{Cl}$ powders prepared at $700^{\circ} \mathrm{C}$ exhibited final discharge cycle capacities of 1039, 1001, 969, 936, $905,879,832$, and $787 \mathrm{~mA} \mathrm{~h} \mathrm{~g}^{-1}$ at current densities of 500, 1000, $1500,2000,2500,3000,4000$, and $5000 \mathrm{~mA} \mathrm{~g}^{-1}$, respectively. When the current density returned to $500 \mathrm{~mA} \mathrm{~g}^{-1}$, the discharge capacity recovered to $1063 \mathrm{~mA} \mathrm{~h} \mathrm{~g}^{-1}$ in spite of the cycling at high current densities, which indicates the good rate performance. Figure $4 \mathrm{e}$ shows the long-term cycling performance of the $\mathrm{Co}_{2}(\mathrm{OH})_{3} \mathrm{Cl}$ pow- ders prepared at $700^{\circ} \mathrm{C}$ at a high current density of $5000 \mathrm{~mA} \mathrm{~g}^{-1}$, from which the discharge capacities for the $2^{\text {nd }}$ and $1000^{\text {th }}$ cycles were determined as 818 and $609 \mathrm{~mA} \mathrm{~h} \mathrm{~g}^{-1}$, respectively. The Coulombic efficiencies of the $\mathrm{Co}_{2}(\mathrm{OH})_{3} \mathrm{Cl}$ powders reached above $99 \%$ from the $15^{\text {th }}$ cycle at a high current density of $5000 \mathrm{~mA} \mathrm{~g}^{-1}$ as shown in Figure 4e.

The Nyquist impedance plots obtained before and after the $1^{\text {st }}$ and $100^{\text {th }}$ cycles under a fully charged state for powders prepared at various temperatures are shown in Figure 5. In this, the mediumfrequency semicircle is assigned to the charge-transfer resistance $\left(R_{c t}\right)$, whereas the line inclined at $\sim 45^{\circ}$ to the real axis corresponds to the lithium diffusion process within the electrodes ${ }^{49-51}$. The diameter of the semicircle obtained for the $\mathrm{Co}_{2}(\mathrm{OH})_{3} \mathrm{Cl}$ powder electrode, before cycling in the medium-frequency region, was slightly smaller than those of the electrodes having primary crystal structures of $\mathrm{CoO}$ and $\mathrm{CoCl}_{2}\left(\mathrm{H}_{2} \mathrm{O}\right)_{2}$ as shown in Figure 5a. Similarly, the charge-transfer resistance of the $\mathrm{Co}_{2}(\mathrm{OH})_{3} \mathrm{Cl}$ powder electrode was 
(a)

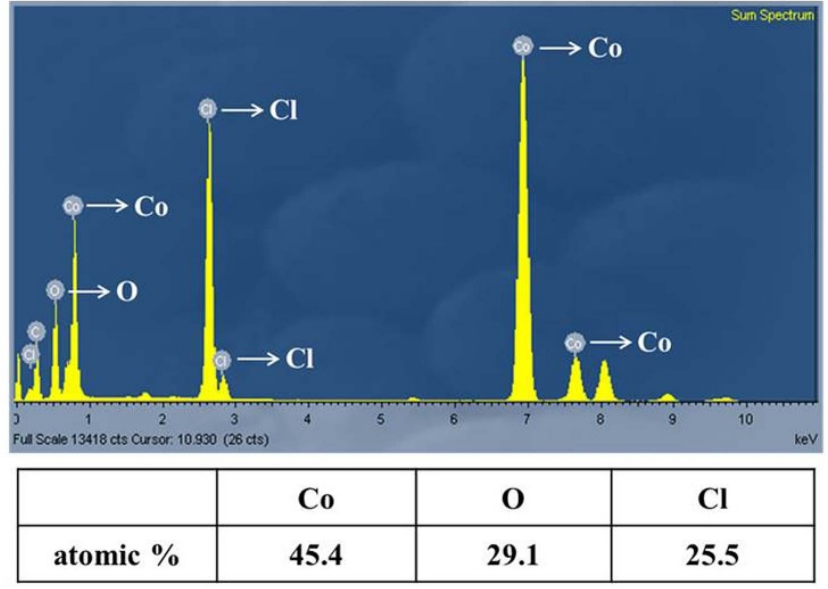

(b)

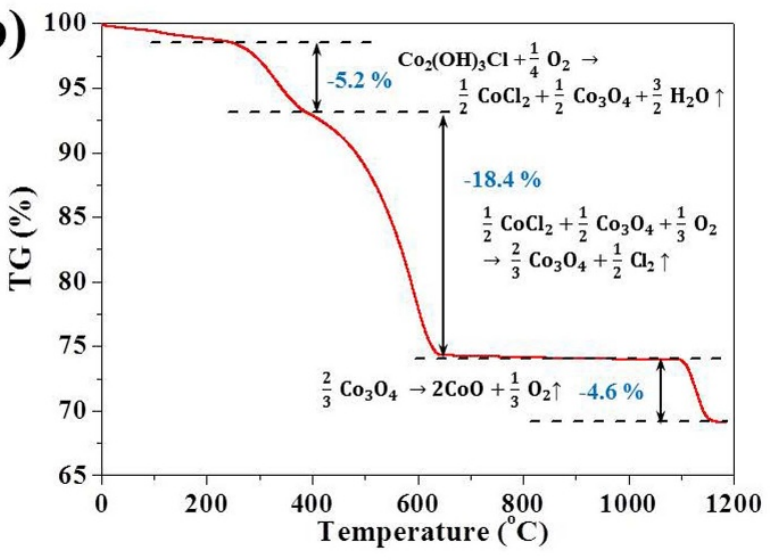

Figure $3 \mid$ (a) EDX spectrum and (b) TG curve of the $\mathrm{Co}_{2}(\mathrm{OH})_{3} \mathrm{Cl}$ powders prepared at $700^{\circ} \mathrm{C}$.
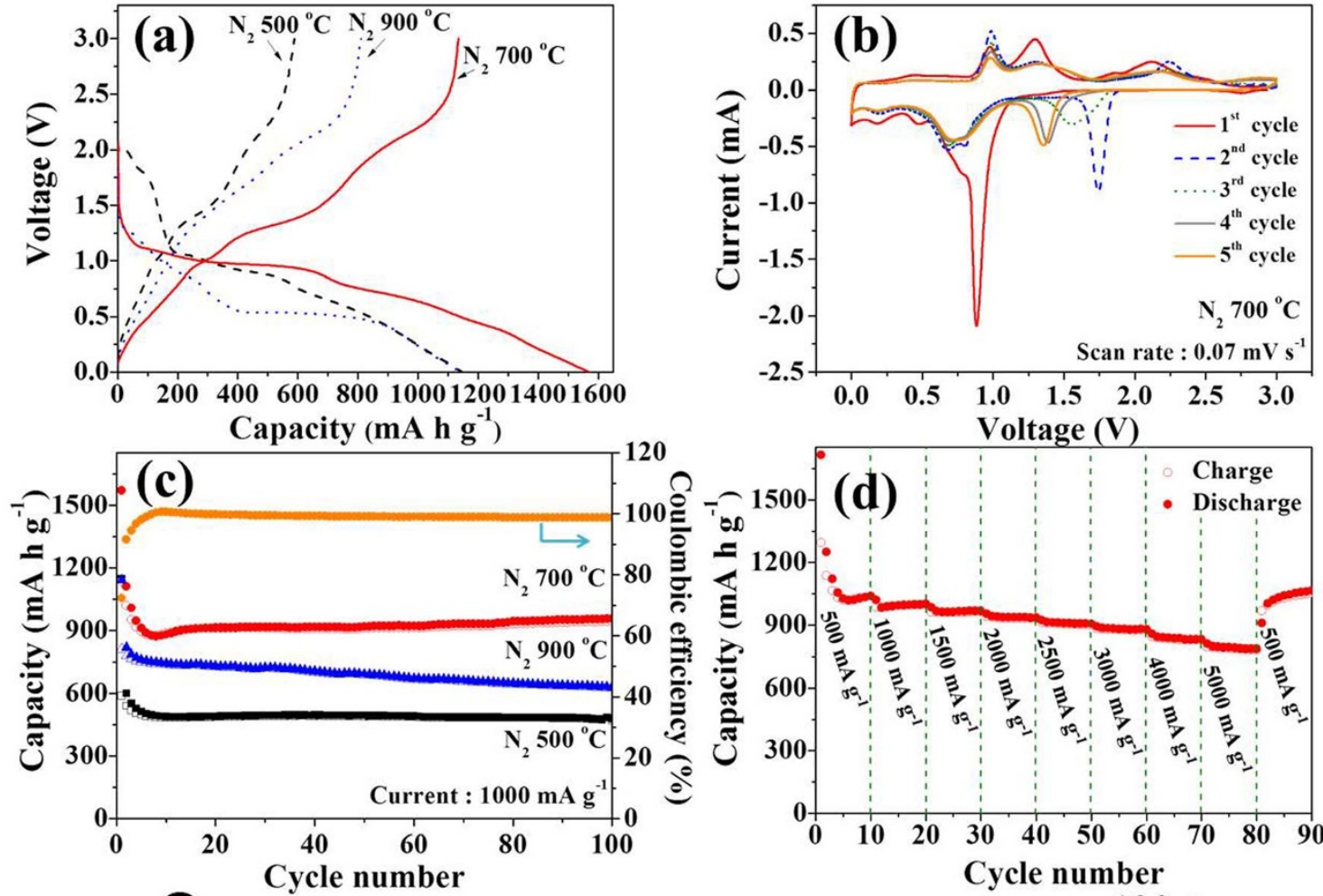

120
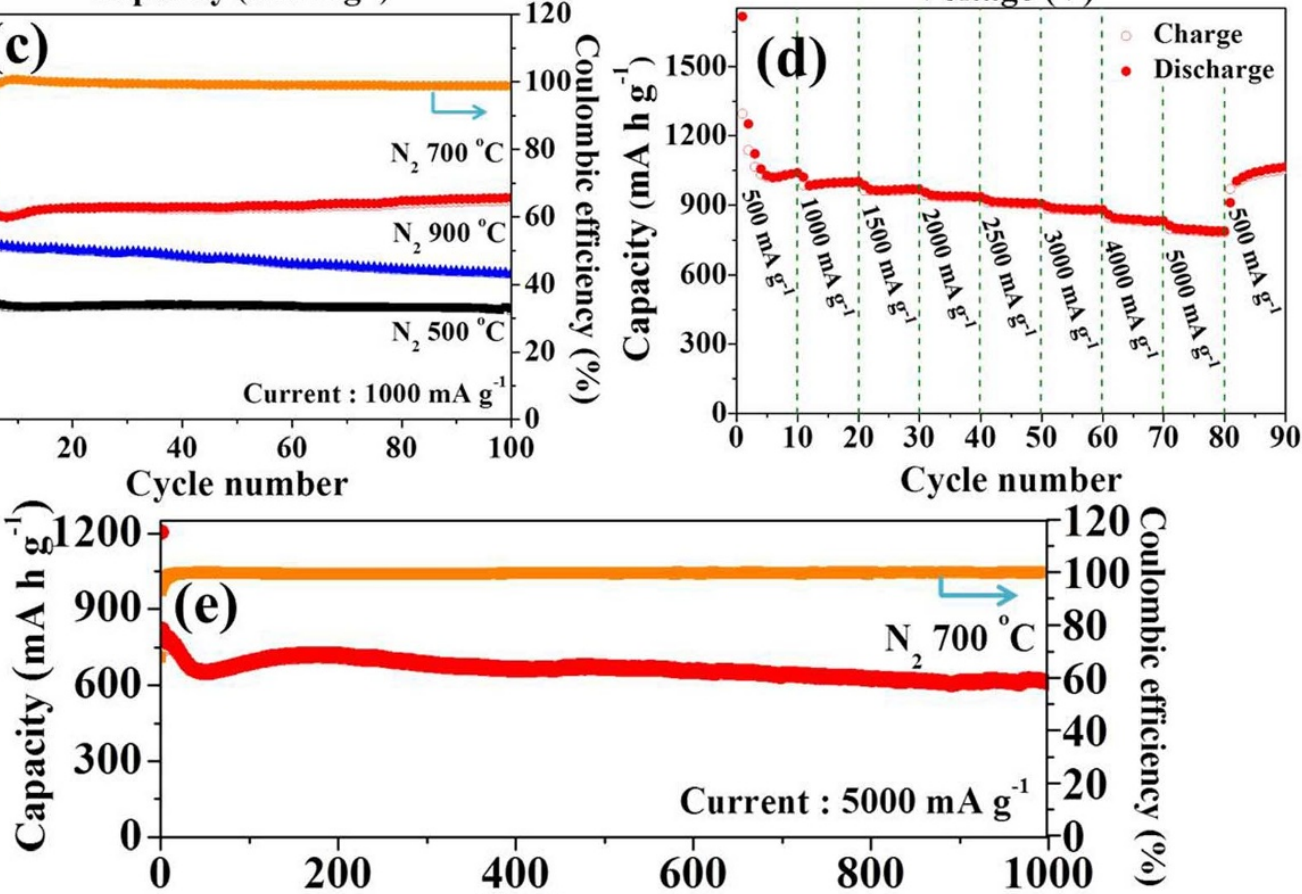

Cycle number

Cycle number

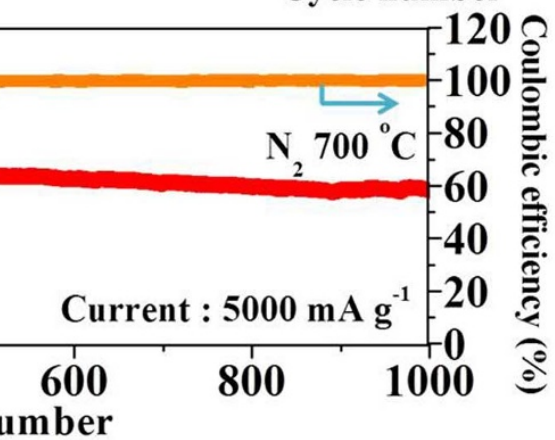

Figure $4 \mid$ Electrochemical properties of the powders prepared by spray pyrolysis at various temperatures: (a) initial discharge/charge voltage profiles at a constant current density at $1000 \mathrm{~mA} \mathrm{~g}^{-1}$, (b) CVs of the $\mathrm{Co}_{2}(\mathrm{OH})_{3} \mathrm{Cl}$ powders, (c) cycling performances at a constant current density of $1000 \mathrm{~mA} \mathrm{~g}^{-1}$, (d) rate performance of the $\mathrm{Co}_{2}(\mathrm{OH})_{3} \mathrm{Cl}$ powders, and (e) cycling performance of the $\mathrm{Co}_{2}(\mathrm{OH})_{3} \mathrm{Cl}$ powders at a high current density of $5000 \mathrm{~mA} \mathrm{~g}^{-1}$. 

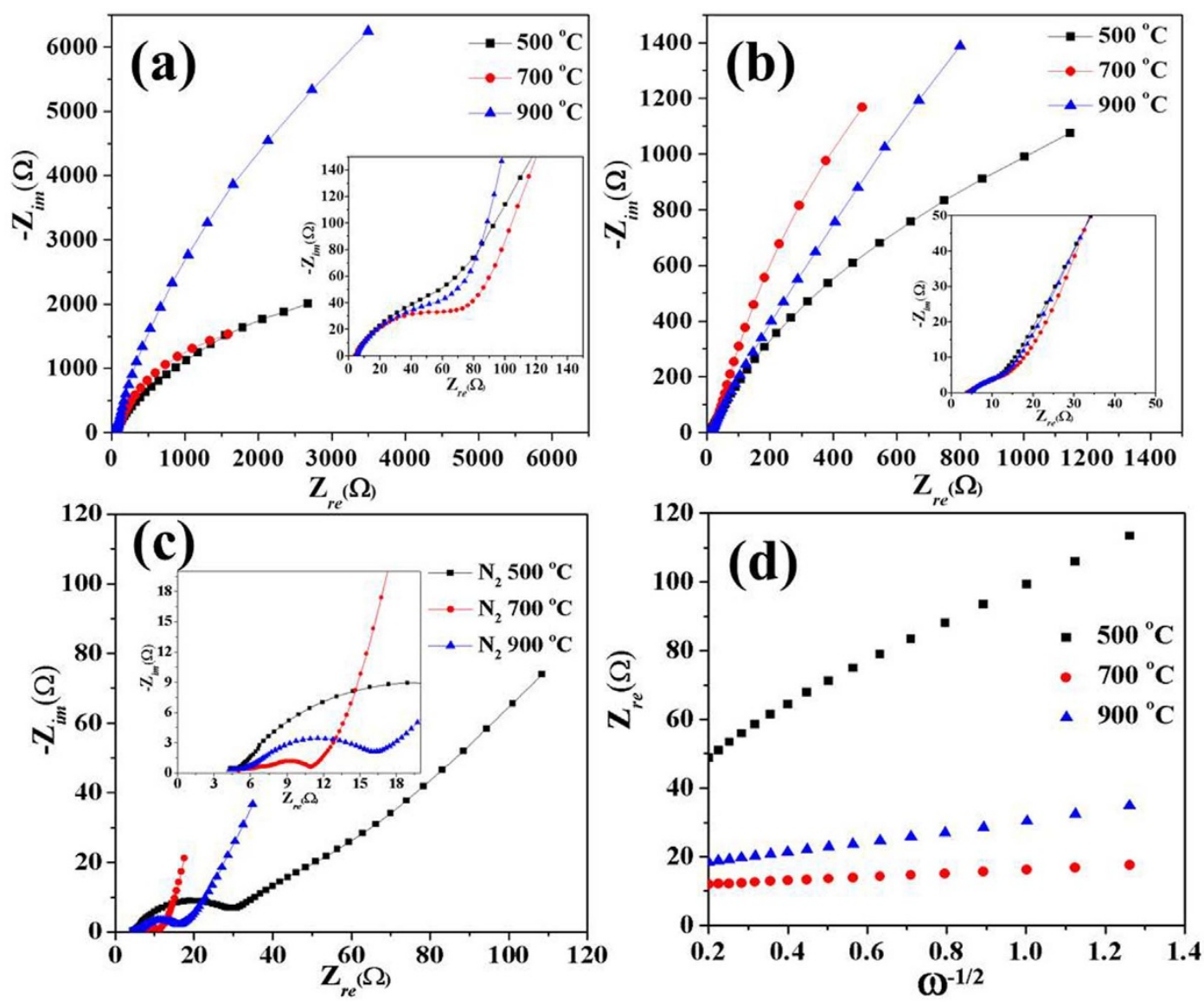

Figure $5 \mid$ Nyquist plots of the electrochemical impedance spectra of the powders prepared at various temperatures (a) before and after the (b) $1^{\text {st }}$ and (c) $100^{\text {th }}$ cycles and (d) relationship between the real part of the impedance spectra $\left(Z_{r e}\right)$ and $\omega^{-1 / 2}$ after 100 cycles.

smaller than those of the $\mathrm{CoO}$ and $\mathrm{CoCl}_{2}\left(\mathrm{H}_{2} \mathrm{O}\right)_{2}$ powder electrodes. The electrodes having primary crystal structures of $\mathrm{Co}_{2}(\mathrm{OH})_{3} \mathrm{Cl}$, $\mathrm{CoO}$, and $\mathrm{CoCl}_{2}\left(\mathrm{H}_{2} \mathrm{O}\right)_{2}$ had similar charge-transfer resistances after first cycles as shown in Figure 5b. However, the diameter of the semicircle obtained for the $\mathrm{Co}_{2}(\mathrm{OH})_{3} \mathrm{Cl}$ powder electrode, after $100^{\text {th }}$ cycling in the medium-frequency region, was smaller than those of the $\mathrm{CoO}$ and $\mathrm{CoCl}_{2}\left(\mathrm{H}_{2} \mathrm{O}\right)_{2}$ powder electrodes as shown in Figure $5 \mathrm{c}$. The structural stability of the $\mathrm{Co}_{2}(\mathrm{OH})_{3} \mathrm{Cl}$ powder resulted in the low charge transfer resistance even after 100 cycles. Figure $5 \mathrm{~d}$ shows the relationship between the real part of the impedance spectra $\left(Z_{r e}\right)$ and $\omega^{-1 / 2}$ (where $\omega$ is the angular frequency in the low frequency region, $\omega=2 \pi f$ ) in the low-frequency region after 100 cycles. The lower slope ( $\sigma$, Warburg impedance coefficient) of the real part of the impedance spectra $\left(Z_{r e}\right)$ versus $\omega^{-1 / 2}$ for the $\mathrm{Co}_{2}(\mathrm{OH})_{3} \mathrm{Cl}$ powder electrode reveals a higher lithium-ion diffusion rate than $\mathrm{CoO}$ and $\mathrm{CoCl}_{2}\left(\mathrm{H}_{2} \mathrm{O}\right)_{2}$ powder electrodes ${ }^{52-54}$. Figure 6 shows the morphologies of the $\mathrm{Co}_{2}(\mathrm{OH})_{3} \mathrm{Cl}$ powders obtained after $100^{\text {th }}$ charging process. The TEM image as shown in Figure 6a shows that the spherical morphology of the $\mathrm{Co}_{2}(\mathrm{OH})_{3} \mathrm{Cl}$ powder was maintained even after repeated charging and discharging processes. However, the powders had amorphous-like structure after cycling. The high resolution TEM image as shown inset image in Figure $6 \mathrm{c}$ shows the lattice fringes with a separation of $0.29 \mathrm{~nm}$, which corresponds to the (300) lattice plane of $\alpha-\mathrm{Co}(\mathrm{OH})_{2}$. The structural stability and high lithium ion diffusion rate of the $\mathrm{Co}_{2}(\mathrm{OH})_{3} \mathrm{Cl}$ powders resulted in superior electrochemical properties even at high current density.

\section{Discussion}

The $\mathrm{Co}_{2}(\mathrm{OH})_{3} \mathrm{Cl}$ powders demonstrated good cycling and rate performances even without carbonaceous additives, which are usually applied to improve the electrochemical properties of transition metal oxides. The pristine $\mathrm{Co}(\mathrm{OH})_{2}$ powders prepared by the hydrothermal process had discharge capacities at a low current density of $200 \mathrm{~mA} \mathrm{~g}^{-1}$ of 1599 and $910 \mathrm{~mA} \mathrm{~h} \mathrm{~g}^{-1}$ for the $1^{\text {st }}$ and $30^{\text {th }}$ cycles, respectively ${ }^{4}$. Meanwhile, the pure $\mathrm{CoCl}_{2}$ powders had respective discharge capacities of 850 and $400 \mathrm{~mA} \mathrm{~h} \mathrm{~g}^{-1}$ for the $1^{\text {st }}$ and $50^{\text {th }}$ cycles, at a low current density of $0.2 \mathrm{C}^{45}$. The $\mathrm{Co}_{2}(\mathrm{OH})_{3} \mathrm{Cl}$ powders introduced in this study therefore present a more promising anode material for LIBs than either $\mathrm{CoCl}_{2}$ or $\mathrm{Co}(\mathrm{OH})_{2}$.

The characteristics of cobalt hydroxychloride $\left[\mathrm{Co}_{2}(\mathrm{OH})_{3} \mathrm{Cl}\right]$ prepared by a one-pot spray pyrolysis were investigated with a view to their potential application as an anode material for LIBs. Spray pyrolysis proved to be efficient for the direct preparation of $\mathrm{Co}_{2}(\mathrm{OH})_{3} \mathrm{Cl}$ powders from a spray solution containing cobalt chloride under a nitrogen atmosphere. Moreover, $\mathrm{Co}_{2}(\mathrm{OH})_{3} \mathrm{Cl}$ powders, which are a solid solution of $\mathrm{Co}(\mathrm{OH})_{2}$ and $\mathrm{CoCl}_{2}$, were found to have superior electrochemical properties than more well-known anode materials such as $\mathrm{CoO}$, as well as individual $\mathrm{CoCl}_{2}$ and $\mathrm{Co}(\mathrm{OH})_{2}$ materials. It was also found that the electrochemical properties of $\mathrm{Co}_{2}(\mathrm{OH})_{3} \mathrm{Cl}$ powders can be improved by optimizing the phase purity and crystallinity, as well as developing novel nanostructures. Therefore, although this is the first such study of $\mathrm{Co}_{2}(\mathrm{OH})_{3} \mathrm{Cl}$ materials, they nonetheless show great promise as a potential anode material for LIBs.

\section{Methods}

Material fabrication. The $\mathrm{Co}_{2}(\mathrm{OH})_{3} \mathrm{Cl}, \mathrm{CoCl}_{2}\left(\mathrm{H}_{2} \mathrm{O}\right)_{2}$, and $\mathrm{CoO}$ powders were prepared by one-pot spray pyrolysis from the spray solution of cobalt chloride by changing the preparation temperatures from 500 to $900^{\circ} \mathrm{C}$ under nitrogen atmosphere. The concentration of cobalt chloride was $0.15 \mathrm{M}$. The spray pyrolysis system consisted of a droplet generator, a high-temperature tubular quartz reactor, 

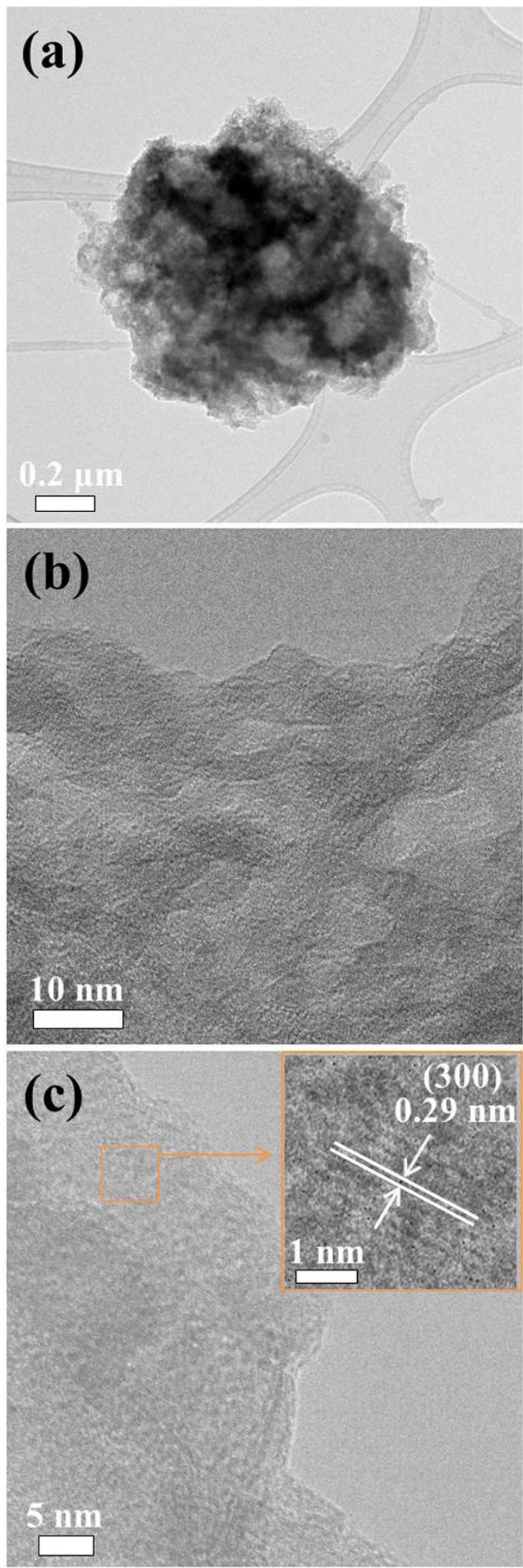

Figure 6 | Morphologies of the $\mathrm{Co}_{2}(\mathrm{OH})_{3} \mathrm{Cl}$ powders obtained after $100^{\text {th }}$ charging process.

and a Teflon bag filter (powder collector). A 1.7-MHz ultrasonic spray generator having six vibrators was used to generate a large number of droplets, which were then carried to the quartz reactor by a carrier gas. The length and diameter of the quartz reactor were 1200 and $50 \mathrm{~mm}$, respectively.

Characterization. The morphologies of the samples were investigated by scanning electron microscopy (SEM, JEOL JSM-6060) and transmission electron microscopy
(FE-TEM, JEM-2100F). The crystal structures of the samples were investigated by $\mathrm{X}$ ray diffractometry (XRD, X'Pert PRO MPD) using $\mathrm{Cu} \mathrm{K} \alpha$ radiation $(\lambda=1.5418 \AA$ ) at the Korea Basic Science Institute (Daegu). Thermal gravimetric analysis (TGA, SDT Q600) was performed in air to determine the amount of carbon in the powders. The surface areas of the samples were measured by the Brunauer-Emmett-Teller (BET) method using $\mathrm{N}_{2}$ as the adsorbate gas.

Electrochemical measurements. The electrochemical properties of the prepared powders were analyzed in a 2032-type coin cell. The anode was prepared from a mixture of the active material, carbon black, and sodium carboxymethyl cellulose (CMC) in a weight ratio of $7: 2: 1$. Li metal and a microporous polypropylene film were used as the counter electrode and the separator, respectively. The electrolyte was $1 \mathrm{M} \mathrm{LiPF}_{6}$ dissolved in a mixture of ethylene carbonate/dimethyl carbonate (EC/ DMC; $1: 1 \mathrm{v} / \mathrm{v}$ ) with $2 \%$ vinylene carbonate. The discharge/charge characteristics of the samples were investigated through cycling in the $0.001-3 \mathrm{~V}$ potential range at various current densities. Cyclic voltammograms were measured at a scan rate of $0.07 \mathrm{mV} \mathrm{s}^{-1}$.

1. McDowell, M. T., Lee, S. W., Nix, W. D. \& Cui, Y. 25th anniversary article: understanding the lithiation of silicon and other alloying anodes for lithium-ion batteries. Adv. Mater. 25, 4966-4985 (2013).

2. Reddy, M. V., Subba Rao, G. V. \& Chowdari, B. V. R. Metal oxides and oxysalts as anode materials for Li ion batteries. Chem. Rev. 113, 5364-5457 (2013).

3. Choi, N. S. et al. Challenges Facing Lithium Batteries and Electrical Double-Layer Capacitors. Angew. Chem. Int. Ed. 51, 9994-10024 (2012).

4. Armand, M. \& Tarascon, J. M. Building better batteries. Nature 451, 652-657 (2008).

5. Winter, M., Besenhard, J. Q., Spahr, M. E. \& Novák, P. Insertion electrode materials for rechargeable lithium batteries. Adv. Mater. 10, 725-762 (1998).

6. Kaskhedikar, N. A. \& Maier, J. Lithium storage in carbon nanostructures. Adv. Mater. 21, 2664-2680 (2009).

7. Wang, C. S., Wu, G. T. \& Li, W. Z. Lithium insertion in ball-milled graphite. J. Power Sources 76, 1-10 (1998).

8. Tarascon, J. M. \& Armand, M. Issues and challenges facing rechargeable lithium batteries. Nature 414, 359-367 (2001).

9. Bruce, P. G., Scrosati, N. \& Tarascon, J. M. Nanomaterials for rechargeable lithium batteries. Angew. Chem. Int. Ed. 47, 2930-2946 (2008).

10. Etacheri, V., Marom, R., Elazari, R., Salitra, G. \& Aurbach, D. Challenges in the development of advanced Li-ion batteries: a review. Energy Environ. Sci. 4, 3243-3262 (2011).

11. Palacín, M. R. Recent advances in rechargeable battery materials: a chemist's perspective. Chem. Soc. Rev. 38, 2565-2575 (2009).

12. Scrosati, B., Hassoun, J. \& Sun, Y. K. Lithium-ion batteries. A look into the future. Energy Environ. Sci. 4, 3287-3295 (2011).

13. Lu, L., Han, X., Li, J., Hua, J. \& Ouyang, M. A review on the key issues for lithiumion battery management in electric vehicles. J. Power Sources 226, 272-288 (2013).

14. Poizot, P., Laruelle, S., Grugeon, S., Dupont, L. \& Tarascon, J. M. Nano-sized transition-metal oxides as negative-electrode materials for lithium-ion batteries. Nature 407, 496-499 (2000).

15. Ji, L., Lin, Z., Alcoutlabi, M. \& Zhang, X. Recent developments in nanostructured anode materials for rechargeable lithium-ion batteries. Energy Environ. Sci. 4 2682-2699 (2011).

16. Wang, Z., Zhou, L. \& Lou, X. W. Metal oxide hollow nanostructures for lithiumion batteries. Adv. Mater. 24, 1903-1911 (2012).

17. Wu, H. B., Chen, J. S., Hng, H. H. \& Lou, X. W. Nanostructured metal oxide-based materials as advanced anodes for lithium-ion batteries. Nanoscale 4, 2526-2542 (2012).

18. Lai, C. H., Lu, M. Y. \& Chen, L. J. Metal sulfide nanostructures: synthesis, properties and applications in energy conversion and storage. J. Mater. Chem. 22, 19-30 (2012).

19. Gao, M. R., Xu, Y. F., Jiang, J. \& Yu, S. H. Nanostructured metal chalcogenides: synthesis, modification, and applications in energy conversion and storage devices. Chem. Soc. Rev. 42, 2986-3017 (2013).

20. Wang, H. et al. $\mathrm{Mn}_{3} \mathrm{O}_{4}$-graphene hybrid as a high-capacity anode material for lithium ion batteries. J. Am. Chem. Soc. 132, 13978-13980 (2010).

21. Li, Y., Tan, B. \& Wu, Y. Mesoporous $\mathrm{Co}_{3} \mathrm{O}_{4}$ nanowire arrays for lithium ion batteries with high capacity and rate capability. Nano Lett. 8, 265-270 (2008).

22. Zhang, W. M., Wu, X. L., Hu, J. S., Guo, Y. G. \& Wan, L. J. Carbon coated $\mathrm{Fe}_{3} \mathrm{O}_{4}$ nanospindles as a superior anode material for lithium-ion batteries. Adv. Funct. Mater. 18, 3941-3946 (2008).

23. Zhou, G. et al. Graphene-wrapped $\mathrm{Fe}_{3} \mathrm{O}_{4}$ anode material with improved reversible capacity and cyclic stability for lithium ion batteries. Chem. Mater. 22, 5306-5313 (2010).

24. Varghese, B. et al. Fabrication of $\mathrm{NiO}$ nanowall electrodes for high performance lithium ion battery. Chem. Mater. 20, 3360-3367 (2008)

25. Courtel, F. M., Duncan, H., Abu-Lebdeh, Y. \& Davidson, I. J. High capacity anode materials for Li-ion batteries based on spinel metal oxides $\mathrm{AMn}_{2} \mathrm{O}_{4}(\mathrm{~A}=\mathrm{Co}, \mathrm{Ni}$, and Zn). J. Mater. Chem. 21, 10206-10218 (2011).

26. Yu, L., Zhang, L., Wu, H. B., Zhang, G. \& Lou, X. W. Controlled synthesis of hierarchical $\mathrm{Co}_{\mathrm{x}} \mathrm{Mn}_{3-\mathrm{x}} \mathrm{O}_{4}$ array micro-/nanostructures with tunable morphology 
and composition as integrated electrodes for lithium-ion batteries. Energy Environ. Sci. 6, 2664-2671 (2013).

27. Mahmood, N., Zhang, C. \& Hou, Y. Nickel sulfide/nitrogen-doped graphene composites: phase-controlled synthesis and high performance anode materials for lithium ion batteries. Small 9, 1321-1328 (2013).

28. Wu, B., Song, H., Zhou, J. \& Chen, X. Iron sulfide-embedded carbon microsphere anode material with high-rate performance for lithium-ion batteries. Chem. Commun. 47, 8653-8655 (2011).

29. Choi, S. H. \& Kang, Y. C. Synthesis for yolk-shell-structured metal sulfide powders with excellent electrochemical performances for lithium-ion batteries. Small 10, 474-478 (2014).

30. Kim, S. W. et al. Energy storage in in vivo synthesizable biominerals. RSC Adv. 2, 5499-5501 (2012)

31. Xiong, S., Chen, J. S., Lou, X. W. \& Zeng, H. C. Mesoporous $\mathrm{Co}_{3} \mathrm{O}_{4}$ and CoO@C topotactically transformed from chrysanthemum-like $\mathrm{Co}\left(\mathrm{CO}_{3}\right)_{0.5}(\mathrm{OH}) \cdot 0.11 \mathrm{H}_{2} \mathrm{O}$ and their lithium-storage properties. Adv. Funct. Mater. 22, 861-871 (2012).

32. Chen, J. S. et al. Shape-controlled synthesis of $\mathrm{Co}_{3} \mathrm{O}_{4}$ nanostructures and their comparative lithium storage properties. ACS Appl. Mater. Interfaces 2, 3628-3635 (2010).

33. Lou, X. W., Deng, D., Lee, J. Y. \& Archer, L. A. Thermal formation of mesoporous single-crystal $\mathrm{Co}_{3} \mathrm{O}_{4}$ nano-needles and their lithium storage properties. J. Mater. Chem. 18, 4397-4401 (2008).

34. García-Martínez, O., Millán, P., Rojas, R. M. \& Torralvo, M. J. Cobalt basic salts as inorganic precursors of cobalt oxides and cobalt metal: thermal behaviour dependence on experimental conditions. J. Mater. Sci. 23, 1334-1350 (1988)

35. Zheng, X., Kawae, T., Yamada, H., Nishiyama, K. \& Xu, C. Coexisting ferromagnetic order and disorder in a uniform system of hydroxyhalide $\mathrm{Co}_{2}(\mathrm{OH})_{3}$ Cl. Phys. Rev. Lett. 97, 274204 (2006).

36. Zheng, M. G., Hagihala, M., Fujihala, M. \& Kawae, T. Recent developments in the magnetic study of the deformed pyrochlore lattice $\mathrm{M}_{2}(\mathrm{OH})_{3} \mathrm{X}(\mathrm{M}=3 \mathrm{~d}$ magnetic ions, $\mathrm{X}=\mathrm{Cl}, \mathrm{Br}$ ) - exotic magnetic order in $\mathrm{Ni}_{2}(\mathrm{OH})_{3} \mathrm{Cl}$ and controlled spin-spin interactions in $\mathrm{Co}_{2}(\mathrm{OH})_{3} \mathrm{Cl}_{1-\mathrm{x}} \mathrm{Br}_{\mathrm{x}}$ and $\left(\mathrm{Co}_{1-\mathrm{x}} \mathrm{Fe}_{\mathrm{x}}\right)_{2}(\mathrm{OH})_{3}$ Cl. J. Phys.: Conf. Ser. 145, 012034 (2009)

37. Hu, Z. A. et al. Synthesis of $\alpha$-cobalt hydroxides with different intercalated anions and effects of intercalated anions on their morphology, basal plane spacing, and capacitive property. J. Phys. Chem. C 113, 12502-12508 (2009).

38. Wang, X. et al. Synthesis of single-crystalline $\mathrm{Co}_{3} \mathrm{O}_{4}$ octahedral cages with tunable surface aperture and their lithium storage properties. J. Phys. Chem. C 113 15553-15558 (2009)

39. Guo, Q., Guo, X. \& Tian, Q. Optionally ultra-fast synthesis of $\mathrm{CoO} / \mathrm{Co}_{3} \mathrm{O}_{4}$ particles using $\mathrm{CoCl}_{2}$ solution via a versatile spray roasting method. Adv. Powder Technol. 21, 529-533 (2010).

40. Chen, C. H. et al. An understanding of anomalous capacity of nano-sized CoO anode materials for advanced Li-ion battery. Electrochem. Commun. 12, 496-498 (2010)

41. Peng, C. et al. Facile ultrasonic synthesis of $\mathrm{CoO}$ quantum dot/graphene nanosheet composites with high lithium storage capacity. ACS Nano 6 1074-1081 (2012)

42. Do, J. S. \& Weng, C. H. Preparation and characterization of $\mathrm{CoO}$ used as anodic material of lithium battery. J. Power Sources 146, 482-486 (2005).

43. Zhao, Z., Geng, F., Bai, J. \& Cheng, H. M. Facile and controlled synthesis of 3D nanorods-based urchinlike and nanosheets-based flowerlike cobalt basic salt nanostructures. J. Phys. Chem. C 111, 3848-3852 (2007).

44. He, Y. S. et al. A Co(OH $)_{2}$-graphene nanosheets composite as a high performance anode material for rechargeable lithium batteries. Electrochem. Commun. 12, 570-573 (2010).

45. Liu, J. I., Cui, W. J., Wang, C. X. \& Xia, Y. Y. Electrochemical reaction of lithium with $\mathrm{CoCl}_{2}$ in nonaqueous electrolyte. Electrochem. Commun. 13, 269-271 (2011)
46. Hu, Y. Y. et al. Origin of additional capacities in metal oxide lithium-ion battery electrodes. Nat. Mater. 12, 1130-1136 (2013).

47. Li, Z. et al. Three-dimensional nanohybrids of $\mathrm{Mn}_{3} \mathrm{O}_{4} /$ ordered mesoporous carbons for high performance anode materials for lithium-ion batteries. J. Mater. Chem. 22, 16640-16648 (2012).

48. Luo, J. et al. Three-dimensional graphene foam supported $\mathrm{Fe}_{3} \mathrm{O}_{4}$ lithium battery anodes with long cycle life and high rate capability. Nano Lett. 13, 6136-6143 (2013).

49. Ko, Y. N., Park, S. B., Jung, K. Y. \& Kang, Y. C. One-pot facile synthesis of antcave-structured metal oxide-carbon microballs by continuous process for use as anode materials in Li-ion batteries. Nano Lett. 13, 5462-5466 (2013).

50. Park, M. S., Kang, Y. M., Wang, G. X., Dou, S. X. \& Liu, H. K. The effect of morphological modification on the electrochemical properties of $\mathrm{SnO}_{2}$ nanomaterials. Adv. Funct. Mater. 18, 455-461 (2008)

51. Chen, X., Zhang, N. \& Sun, K. Facile fabrication of $\mathrm{CuO}$ mesoporous nanosheet cluster array electrodes with super lithium-storage properties. J. Mater. Chem. 22, 13637-13642 (2012).

52. Chen, Y. S. et al. Microscopic mechanism for unipolar resistive switching behaviour of nickel oxides. J. Phys. D: Appl. Phys. 45, 065303 (2012).

53. Choi, S. H. \& Kang, Y. C. Yolk-Shell, hollow, and single-crystalline $\mathrm{ZnCo}_{2} \mathrm{O}_{4}$ Powders: preparation using a simple one-pot process and application in lithiumion batteries. ChemSusChem 6, 2111-2116 (2013).

54. Takami, N., Satoh, A., Hara, M. \& Ohsaki, T. Structural and kinetic characterization of lithium intercalation into carbon anodes for secondary lithium batteries. J. Electrochem. Soc. 142, 371-379 (1995).

\section{Acknowledgments}

This work was supported by the National Research Foundation of Korea (NRF) grant funded by the Korea government (MEST) (No. 2012R1A2A2A02046367). This work was supported by the Energy Efficiency \& Resources Core Technology Program of the Korea Institute of Energy Technology Evaluation and Planning (KETEP), granted financial resource from the Ministry of Trade, Industry \& Energy, Republic of Korea (201320200000420)

\section{Author contributions}

G.D.P. and Y.C.K. devised the concept, designed the experiment, and wrote the manuscript. G.D.P. and Y.N.K. performed the experiments and analyzed the data. Y.C.K. supervised the project. All authors discussed the results and contributed in this manuscript.

\section{Additional information}

Supplementary information accompanies this paper at http://www.nature.com/ scientificreports

Competing financial interests: The authors declare no competing financial interests.

How to cite this article: Park, G.D., Ko, Y.N. \& Kang, Y.C. Electrochemical properties of cobalt hydroxychloride microspheres as a new anode material for Li-ion batteries. Sci. Rep. 4, 5785; DOI:10.1038/srep05785 (2014)

This work is licensed under a Creative Commons Attribution-NonCommercialShareAlike 4.0 International License. The images or other third party material in this article are included in the article's Creative Commons license, unless indicated otherwise in the credit line; if the material is not included under the Creative Commons license, users will need to obtain permission from the license holder in order to reproduce the material. To view a copy of this license, visit http:/ creativecommons.org/licenses/by-nc-sa/4.0/ 